Documentation of Artifacts from Sam Whiteside Collection from Sites in the Sabine and Neches River Basins, Upshur, Smith, and Cherokee Counties, Texas

Timothy K. Perttula

Heritage Research Center, Stephen F. Austin State University

Follow this and additional works at: https://scholarworks.sfasu.edu/ita

Part of the American Material Culture Commons, Archaeological Anthropology Commons, Environmental Studies Commons, Other American Studies Commons, Other Arts and Humanities Commons, Other History of Art, Architecture, and Archaeology Commons, and the United States History Commons

Tell us how this article helped you.

This Article is brought to you for free and open access by the Center for Regional Heritage Research at SFA ScholarWorks. It has been accepted for inclusion in Index of Texas Archaeology: Open Access Gray Literature from the Lone Star State by an authorized editor of SFA ScholarWorks. For more information, please contact cdsscholarworks@sfasu.edu. 
Documentation of Artifacts from Sam Whiteside Collection from Sites in the Sabine and Neches River Basins, Upshur, Smith, and Cherokee Counties, Texas

\section{Creative Commons License}

(c) (1) (9)

This work is licensed under a Creative Commons Attribution-NonCommercial 4.0 International License 


\title{
Documentation of Artifacts from Sam Whiteside Collection from Sites in the Sabine and Neches River Basins, Upshur, Smith, and Cherokee Counties, Texas
}

\author{
Timothy K. Perttula
}

\section{Introduction}

Sam Whiteside was an active avocational archaeologist in East Texas in the 1950s and early 1960s, and investigated a number of important ancestral Caddo sites in Smith and Upshur counties (Walters 2004:119-120). Much of his collection of artifacts and notes has been donated to the Texas Archeological Research Laboratory at The University of Texas, and there have been several published studies of the archaeological findings from these sites (Perttula and Wilson 2000; Walters and Haskins 1998, 2000). In this article, I document select collections that have recently become available for study from sites in the Sabine and Neches River basin in Upshur, Smith, and Cherokee counties.

\section{Sabine River Basin Sites}

\section{Boxed Springs}

The Boxed Springs site (41UR30) is an Early Caddo period (ca. A.D. 900-1200) multiple mound center and village on terrace and upland landforms immediately adjacent to the Sabine River, and just upstream from its confluence with Big Sandy Creek (Perttula 2011; Perttula and Wilson 2000). Sam Whiteside conducted excavations in Mound A and Mound D, and the one artifact from the collection documented here is from Burial 1 in Mound A (Perttula and Wilson 2000:39). Burial 1 "consisted of a charcoal stain and fragments of human bone... some of which were charred, as well as a human molar, all in the eastern part of the mound."

The one Burial 1 artifact documented herein (specimen no. 17) is a large biface, or small sword (cf. Shafer 2011:89-90 and Figure 44) (Figure 1). The biface is made from a dark grayish-brown and brown chert, possibly Woodford chert from the Ouachita Mountains of southeastern Oklahoma or from a Central Texas source. The biface would need to be examined under UV fluorescence to determine its likely source area; in any case, the artifact is not made from a local Sabine River chert source.

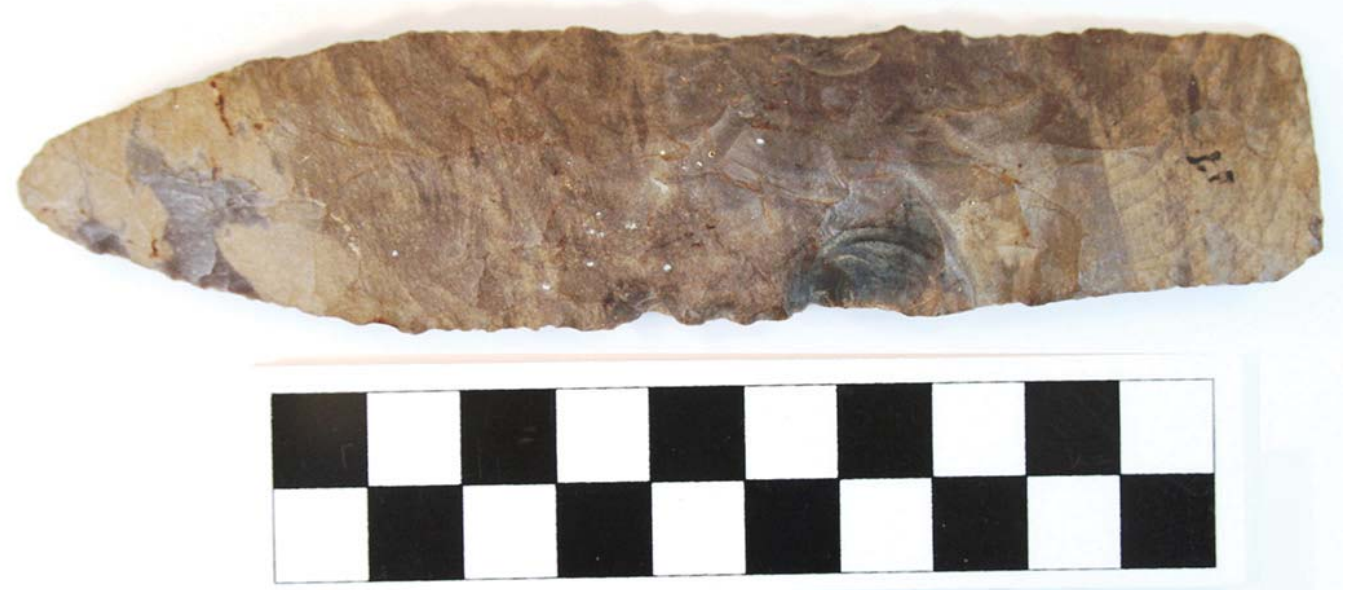

Figure 1. Large Biface or small sword from Burial 1 (no. 17) at the Boxed Springs site. 
The biface has a straight base, parallel edges to past its mid-length, where the edges converge to the tip (see Figure 1). It has been bifacially knapped and sharpened, and the edges are not smoothed. There is evidence of apparent surface smoothing on both faces. Shafer (personal communication, November $29,2015)$ suggests that the technology of the biface "looks more Archaic, but as we know from the Davis tombs, the early Caddo often picked up and recycled artifacts."

\section{Bryan Hardy}

The Bryan Hardy site (41SM55) is an ancestral Caddo site of Middle Caddo period age on Ray Creek in the Sabine River basin (Walters and Haskins 2000; Whiteside 1959). The one available calibrated radiocarbon date of A.D. 1297-1391 was obtained on a charred post from House 1 (Walters and Haskins 2000:4).

During Mr. Whiteside's 1958 excavations, in addition to the exposure of House 1 under a constructed earthen mound at the southern part of the site, and two circular houses (Houses 2 and 3) about $60 \mathrm{~m}$ to the north of House 1, he excavated three Caddo burials: Burial 1 by House 2, and Burials 2-3 about $5.5 \mathrm{~m}$ southeast of House 1 (Walters and Haskins 2000:Figure 2). Two ceramic vessels, the sole funerary offerings from Burials 2 and 3 , are documented in this article.

SITE NAME OR SITE NUMBER: Bryan Hardy (41SM55)

VESSEL NO.: Burial 2

VESSEL FORM: Jar with two strap handles (48 x $25 \mathrm{~mm}$ in length and width) (Figure 2a) and four attachments for legs (now missing) (Figure 2b)

NON-PLASTICS AND PASTE: grog and bone

RIM AND LIP FORM: Everted rim

CORE COLOR: F (fired in a reducing environment and cooled in the open air)

INTERIOR SURFACE COLOR: brown; fire clouds on the rim and body

EXTERIOR SURFACE COLOR: brown; fire clouds on the rim, body, and base

WALL THICKNESS (IN MM): rim, $6.2 \mathrm{~mm}$

INTERIOR SURFACE TREATMENT: smoothed

EXTERIOR SURFACE TREATMENT: none

HEIGHT (IN CM): 13.9

ORIFICE DIAMETER (IN CM): 11.5

DIAMETER AT BOTTOM OF RIM OR NECK (IN CM): 12.2

BASE DIAMETER (IN CM) AND SHAPE OF BASE: 10.2; circular and flat

ESTIMATED VOLUME (IN LITERS): 1.0 
DECORATION (INCLUDING MOTIF AND ELEMENTS WHEN APPARENT): Half of the vessel rim has three horizontal rows of fingernail punctations (Figure 2a), while the other half has cross-hatched fingernail punctated rows, three that are horizontal and 19 rows that are vertical in orientation. The vessel body has six upper and six lower sets of triangular incised elements separated by incised meandering scroll lines (Figure 2a). Each of the upper and lower triangular incised elements have between four and seven horizontal rows of fingernail punctations. The handles have four vertical rows of either incised lines or fingernail punctations. There are also two $8 \mathrm{~mm}$ diameter appliqued nodes on the top of the two handles. Walters and Haskins (2000:25) suggest that this vessel "is probably a trade" from a Middle Caddo period Sanders phase group on the Red River.

PIGMENT USE AND LOCATION ON VESSEL: none

TYPE AND VARIETY (IF KNOWN): cf. Monkstown Fingernail Impressed (see Suhm and Jelks 1962:Plate 55b)

SITE NAME OR SITE NUMBER: Bryan Hardy (41SM55)

VESSEL NO.: Burial 3

VESSEL FORM: Carinated bowl with four lip tabs

NON-PLASTICS AND PASTE: grog

RIM AND LIP FORM: Inverted rim and flat lip

CORE COLOR: $\mathrm{F}$ (fired in a reducing environment and cooled in the open air)
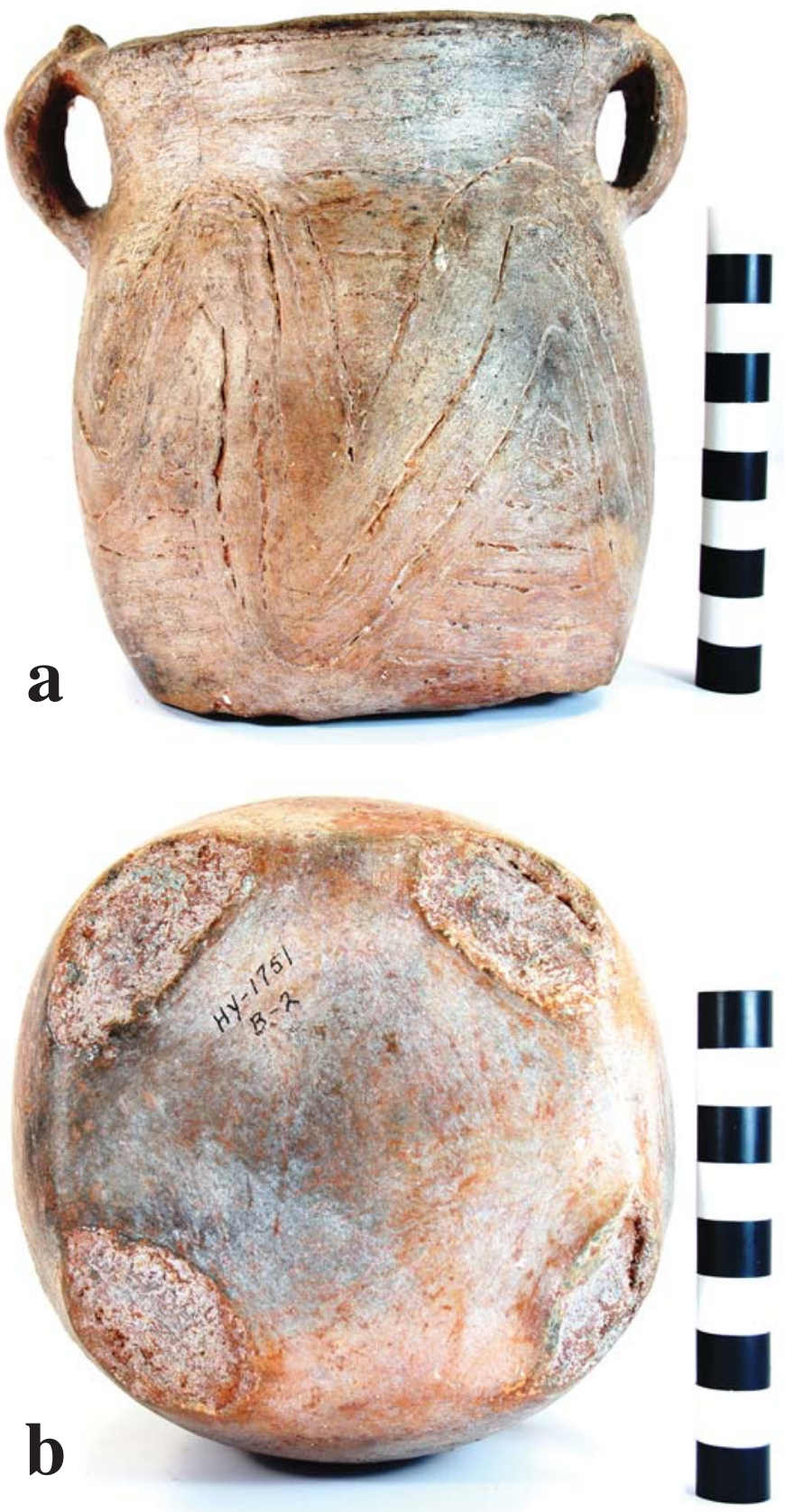

Figure 2. cf. Monkstown Fingernail Impressed jar from Burial 2 at the Bryan Hardy site: a, side view; b, view of area of missing leg attachments.

INTERIOR SURFACE COLOR: brown; fire clouds on the lip and rim

EXTERIOR SURFACE COLOR: brown: fire clouds on the lip, rim, body, and base

WALL THICKNESS (IN MM): rim, $6.1 \mathrm{~mm}$

INTERIOR SURFACE TREATMENT: smoothed 
EXTERIOR SURFACE TREATMENT: smoothed

HEIGHT (IN CM): 5.6

ORIFICE DIAMETER (IN CM): 10.8

DIAMETER AT BOTTOM OF RIM OR NECK (IN CM): 12.2

BASE DIAMETER (IN CM) AND SHAPE OF BASE: 6.2; circular and flat

ESTIMATED VOLUME (IN LITERS): 0.4

DECORATION (INCLUDING MOTIF AND ELEMENTS WHEN APPARENT):

The rim panel on this carinated bowl is delimited by single upper and lower horizontal engraved lines. Within the panel are a series of four rectangular panels divided by sets of two vertical engraved lines or zones. These vertical sets or zones of engraved lines are either undecorated, filled with hatched lines, or have an oval-shaped element with two hatched corners (Figure 3). The panels themselves have combinations of either oval and/or triangular elements with hatched lines, concentric semi-circles and small ovals, or a triangle element with hatched corners. Several of these elements are present on Frankston phase vessels that represent regional varieties of Poynor Engraved (see Perttula 2011:Figure 6-65), but not in the particular unique combination of rectangular panels and engraved decorative elements noted on this vessel from the Bryan Hardy site. It is likely that this vessel represents a stylistic precursor to post-A.D. 1400 Poynor Engraved vessels made in the upper Neches River basin.

\section{PIGMENT USE AND LOCATION ON VESSEL: none}

TYPE AND VARIETY (IF KNOWN): Unidentified fine ware

In addition to two ceramic vessels, Burial 1 (likely that of an infant) at the Bryan Hardy site had a rather unique ceramic dipper or spoon funerary offering (Walters and Haskins 2000:7). Burial 1 was alongside the northeastern wall of House 2 (Walters and Haskins 2000:Figure 5), and in addition to the ceramic dipper or spoon were two ceramic vessels: a plain bowl and a bird effigy bowl. The dipper or spoon, tempered with grog and burned bone pieces, is $69.6 \mathrm{~mm}$ in length and a maximum of $17.1 \mathrm{~mm}$ in width; the dipper or spoon has a rounded handle (Figure 4) that is 10.3 $\mathrm{mm}$ in width at its end. The opening of the

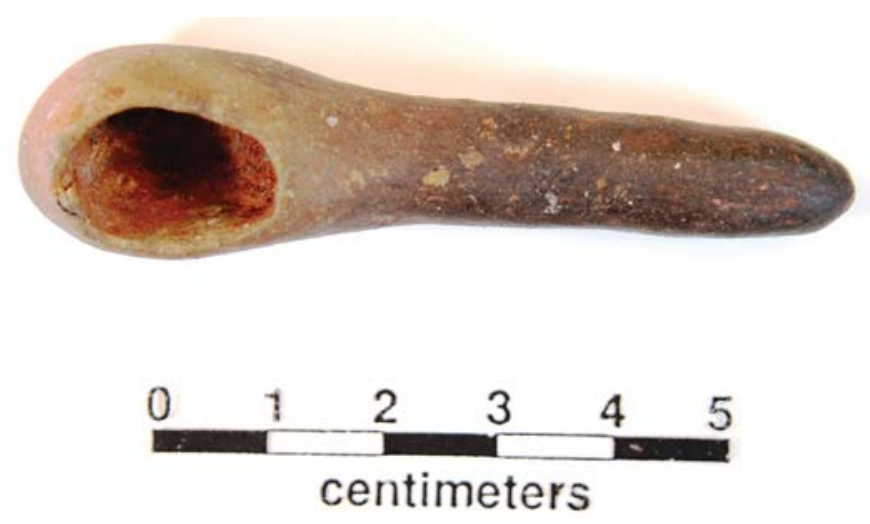

Figure 4. Ceramic dipper or spoon from Burial 1 at the Bryan Hardy site. 
dipper or spoon ranges between 13-17 $\mathrm{mm}$ in orifice diameter. The walls of the spoon or dipper opening are only $2.4 \mathrm{~mm}$ in thickness.

\section{Neches River Basin Sites}

\section{$41 C E 39$}

This site is on an upland landform overlooking the confluence of Stone Chimney Creek and the Neches River, now under the waters of Lake Palestine (see Johnson 1961:231 and Figure 1). Recovered artifacts from the site during survey investigations indicate that it had a Woodland period component, marked by a Gary dart point (Johnson 1961:Figure 21), and an ancestral Caddo component of Late Caddo period, Frankston phase affiliation. The proportion of brushed sherds in the decorated sherd assemblage (75.2 percent) as well as a brushed-other wet paste sherd ratio of 3.70 (Johnson 1961:231) suggests that the Caddo component dates to the latest Frankston phase, from ca. A.D. 1560-1680 (Perttula and Walters 2016:Table 22).

The sole artifact I have documented from 41CE39 is a light gray Pontchartrain dart point (Figure 5). The point has a narrow straight stem, a slightly convex base, and small downward-pointing barbs. It is $117.0 \mathrm{~mm}$ in length, $43.0 \mathrm{~mm}$ in width, 8.6 $\mathrm{mm}$ thick, and has a stem width of 14.9 mm. According to Turner et al. (2011:153), Pontchartrain points date from ca. 2000 B.C. to A.D. 500 , encompassing most of the Late Archaic period and much of the Woodland period in East Texas.

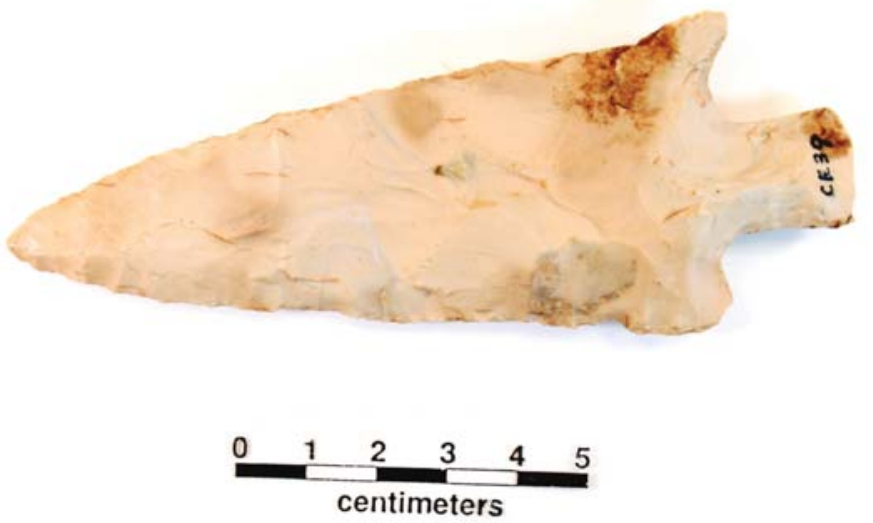

Figure 5. Pontchartrain dart point from $41 \mathrm{CE} 39$ in the Sam Whiteside collection.

\section{Indian Creek}

The exact provenience in Smith County of the one ancestral Caddo vessel from Indian Creek is not known. However, Indian Creek is a western-flowing tributary of the Neches River, and the creek enters the Neches River in what is now the very northern end of Lake Palestine (Johnson 1961:Figure 1). Since Sam Whiteside was an active participant in the Lake Palestine survey (Johnson 1961:215; Walters 2004:119), it is likely that this vessel is from an unrecorded Caddo site in the Lake Palestine area of East Texas.

SITE NAME OR SITE NUMBER: Indian Creek

VESSEL NO.: none

VESSEL FORM: Carinated bowl, globular shape

NON-PLASTICS AND PASTE: grog

RIM AND LIP FORM: Direct rim and rounded lip

CORE COLOR: F (fired in a reducing environment and cooled in the open air)

INTERIOR SURFACE COLOR: brown 
EXTERIOR SURFACE COLOR: brown; fire clouds on the rim and base

WALL THICKNESS (IN MM): rim, $4.4 \mathrm{~mm}$

INTERIOR SURFACE TREATMENT: smoothed

EXTERIOR SURFACE TREATMENT: burnished

HEIGHT (IN CM): 5.4

ORIFICE DIAMETER (IN CM): 7.0

DIAMETER AT BOTTOM OF RIM OR NECK (IN CM): 7.7

BASE DIAMETER (IN CM) AND

SHAPE OF BASE: 5.1 ; circular and flat

ESTIMATED VOLUME (IN LITERS): 0.23

DECORATION (INCLUDING MOTIF AND ELEMENTS WHEN APPARENT):

The rim panel is delimited by single upper and lower horizontal engraved lines. Within this panel are eight sets of closelyspaced vertical engraved lines (Figure 6) that form a series of rectangular panels around the vessel. The creation of simple rectangular panels resembles the stylistic character of some Poynor Engraved, var. Blackburn vessels from the upper Neches River basin. Seven of the sets have five vertical engraved lines, but one set has nine vertical engraved lines.

\section{PIGMENT USE AND LOCATION ON} VESSEL: none

TYPE AND VARIETY (IF KNOWN): cf. Poynor Engraved, var. Blackburn (Perttula 2011:Figure 6-64a)

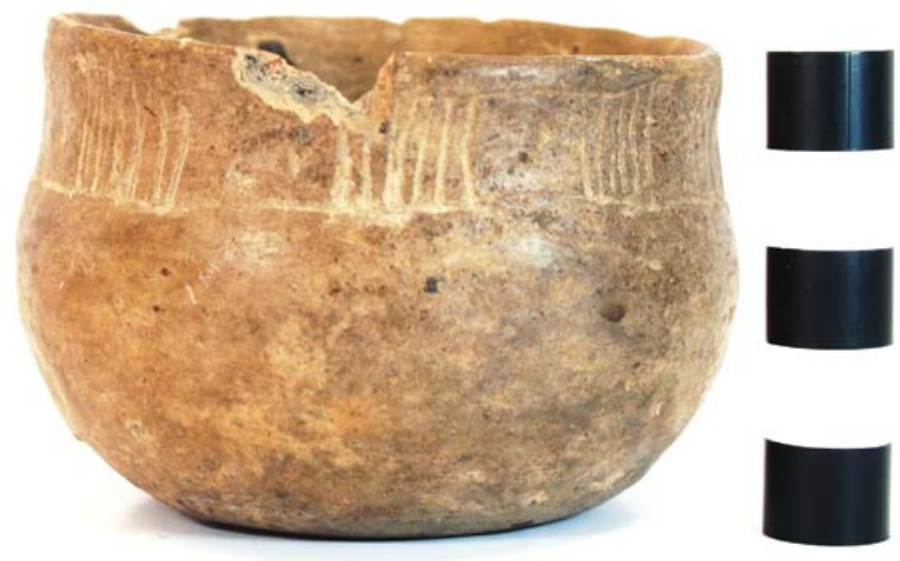

Figure 6. cf. Poynor Engraved, var. Blackburn carinated bowl from Indian Creek, Smith County, Texas.

Poynor Engraved, var. Blackburn vessels occur in ancestral Caddo Frankston phase components that date from ca. A.D. 1400-1680 (Perttula 2011:Table 6-37). They are most common, however, in ca. A.D. 1480-1560 contexts in the upper Neches River basin.

\section{Summary and Conclusions}

Sam Whiteside was an active avocational archaeologist in East Texas in the 1950s and early 1960s, and he conducted important investigations at Caddo sites in Smith, Upshur, and Cherokee counties. The majority of the collections and records Whiteside obtained from these sites have been donated to the Texas Archeological Research Laboratory at The University of Texas at Austin, but recently (November 
2015) a few undocumented artifacts from the Whiteside collection became available for study, thanks to Mark Walters and Dr. James B. Whiteside.

The documented artifacts are from the Boxed Springs (41UR30) and Bryan Hardy (41SM55) sites in the Sabine River basin, and from 41CE39 and the Indian Creek locality in the Neches River basin. The oldest artifact in this portion of the Whiteside collection, dating either to the Late Archaic or Woodland periods, is a light gray Pontchartrain dart point from 41CE39. The other documented artifacts are from ancestral Caddo contexts, including a chert biface or small sword from an Early Caddo period burial at the Boxed Springs site, two vessels (an incised-punctated jar from Burial 2 and an engraved carinated bowl from Burial 3) and a ceramic dipper-spoon (from Burial 1) from a $14^{\text {th }}$ century A.D. Middle Caddo period occupation at the Bryan Hardy site, and a Late Caddo period Frankston phase carinated bowl with engraved decorative elements that compare favorably to Poynor Engraved, var. Blackburn from the Indian Creek locality.

\section{Acknowledgments}

Thanks to Mark Walters for the opportunity to document these selected artifacts from the Sam Whiteside collection. Harry J. Shafer provided comments on the biface from a photograph of the Boxed Springs site artifact. Bo Nelson took the photographs used herein.

\section{References Cited}

Johnson, L., Jr.

1961 An Archeological Survey of Blackburn Crossing Reservoir on the Upper Neches River. Bulletin of the Texas Archeological Society 31:213-238.

Perttula, T. K.

2011 The Ceramic Artifacts from the Lang Pasture Site (41AN38) and the Place of the Site within an Upper Neches River Basin Caddo Ceramic Tradition. In Archeological Investigations at the Lang Pasture Site (41AN38) in the Upper Neches River Basin of East Texas, assembled and edited by T. K. Perttula, D. B. Kelley, and R. A. Ricklis, pp. 145-320. Archeological Studies Program Report No. 129, Texas Department of Transportation, Environmental Affairs Division, Austin.

Perttula, T. K. (assembler)

2011 Archaeological and Archaeogeophysical Investigations at an Early Caddo Mound Center in the Sabine River Basin of East Texas, Special Publication No. 15. Friends of Northeast Texas Archaeology, Austin and Pittsburg.

Perttula, T. K. and M. Walters

2016 Caddo Archaeology in the Caddo Creek Valley of the Upper Neches River Basin, Anderson and Henderson Counties, Texas. Special Publication No. 43. Friends of Northeast Texas Archaeology, Austin and Pittsburg.

Perttula, T. K. and D. E. Wilson, with contributions by M. Walters

2000 An Early Caddoan Period Cremation from the Boxed Springs Mound Site (41UR30) in Upshur County, Texas, and a Report on Previous Archaeological Investigations. Journal of Northeast Texas Archaeology 12:31-71.

Shafer, H. J.

2011 Boxed Springs Mound Site (41UR30) Lithic Analysis. In Archaeological and Archaeogeophysical Investigations at an Early Caddo Mound Center in the Sabine River Basin of East Texas, assembled by T. K. Perttula, pp. 78-111. Special Publication No. 15. Friends of Northeast Texas Archaeology, Austin and Pittsburg. 
Suhm, D. A. and E. B. Jelks (editors)

1962 Handbook of Texas Archeology: Type Descriptions. Special Publication No. 1, Texas Archeological Society, and Bulletin No. 4, Texas Memorial Museum, Austin. Reprinted in 2009, Gustav's Library, Davenport, Iowa.

Turner, E. S., T. R. Hester, and R. L. McReynolds

2011 Stone Artifacts of Texas Indians. Taylor Trade Publishing, Lanham, Maryland.

Walters, M.

2004 A Profile in East Texas Archeology. Bulletin of the Texas Archeological Society 75:119-121.

Walters, M. and P. Haskins

1998 Archaeological Investigations at the Redwine Site (41SM193), Smith County, Texas. Journal of Northeast Texas Archaeology 11:1-38.

2000 The Bryan Hardy Site (41SM55), Smith County, Texas. Journal of Northeast Texas Archaeology 12:1-26.

Whiteside, S.

1959 Vessel from the Bryan Hardy Site. Ancient News 1, No. 1. News Letter of the East Texas Archeological Society, Tyler. 